\title{
Jubileusz 90-lecia Akademii Wychowania Fizycznego Józefa Piłsudskiego w Warszawie
}

\section{Anna Pawlikowska-Piechotka}

\section{STRESZCZENIE}

Rok 2019 jest rokiem szczególnym, z uwagi na 90. rocznicę powołania uczelni. W latach 1929-2019 mury warszawskiej Akademii Wychowania Fizycznego Józefa Piłsudskiego opuściło ponad 50000 absolwentów, wypromowano licznych doktorów i doktorów habilitowanych, zbudowano poważny potencjał naukowo-badawczy. Obecnie studiuje na pięciu wydziałach i dziewięciu kierunkach 4557 studentów. Absolwenci mają wysokie kwalifikacje, odpowiadające potrzebom społeczeństwa XXI w.: są zatrudniani jako nauczyciele, trenerzy, instruktorzy, fizjoterapeuci, pielęgniarze, kosmetolodzy i specjaliści terapii zajęciowej - są wysoko cenionymi specjalistami zatrudnianymi w Polsce i w innych krajach w Europie.

Z okazji Jubileuszu organizowane są konferencje naukowe, sympozja, publikacje, wystawy, imprezy sportowe i kulturalne - podkreślające chlubną tradycję i podsumowujące znaczący dorobek uczelni.

Słowa kluczowe: AWF Warszawa, historia i tradycja uczelni, jubileusz 90-lecia

\section{Lata 1927-1929}

Historia Akademii Wychowania Fizycznego w Warszawie rozpoczyna się niespełna w dziesięć lat po zakończeniu I wojny Światowej, w okresie II RP.

Nie był to okres sprzyjający tak ambitnym inwestycjom, ale po odzyskaniu niepodległości dominowała wśród Polaków determinacja wskrzeszenia w wolnym kraju za wszelką cenę życia kulturalnego, oświaty i sportu, wychowania młodego pokolenia zgodnie z najnowszymi europejskimi zasadami. W Polsce tego okresu, młodym państwie zniszczonym kolejnymi działaniami wojennymi, borykającym się z poważnymi problemami zewnętrznymi (skomplikowana sytuacja międzynarodowa) i wewnętrznymi (trudne jednoczenie kraju po okresie zaborów, problemy gospodarcze i kulturowe, zapóźnienie cywilizacyjne Galicji i Kresów Wschodnich) - wydatki na inwestycje oświaty i sportu musiały być z oczywistych względów znacząco ograniczane. Panowało jednak silne przekonanie, że energiczne działania w tej dziedzinie są konieczne, bowiem nad polskim społeczeństwem ciążyły ponad dwustuletnie zaniedbania, wyniszczenie biologiczne narodu i zrujnowanie $90 \%$ obszaru po dwóch kolejnych wojnach - światowej i bolszewickiej. Niezależnie zatem od wymienionych trudnych uwarunkowań, po uzyskaniu niepodległości, decydowano się na poważne inwestycje $\mathrm{w}$ różnych sektorach dzięki patriotycznemu zapałowi, wierze $\mathrm{w}$ odbudowę 
wolnego kraju i uzyskanie poziomu cywilizacyjnego zamożnych krajów Europy Zachodniej, a także dzięki wsparciu i jasnej w tym zakresie polityce rządu.

Chociaż słaba kondycja ekonomiczna państwa teoretycznie wykluczała poważne i systematyczne nakłady na bazę materialną dla oświaty i sportu, w roku 1927 Rada Naukowa Wychowania Fizycznego pod przewodnictwem Marszałka Józefa Piłsudskiego, podjęła decyzję powołania wyższej uczelni w Warszawie, mającej zadanie kształcenia instruktorów sportu, trenerów sportu wyczynowego i nauczycieli wychowania fizycznego na potrzeby oświaty i wojska. Z uwagi na znaczenie wychowania fizycznego dla obronności państwa,

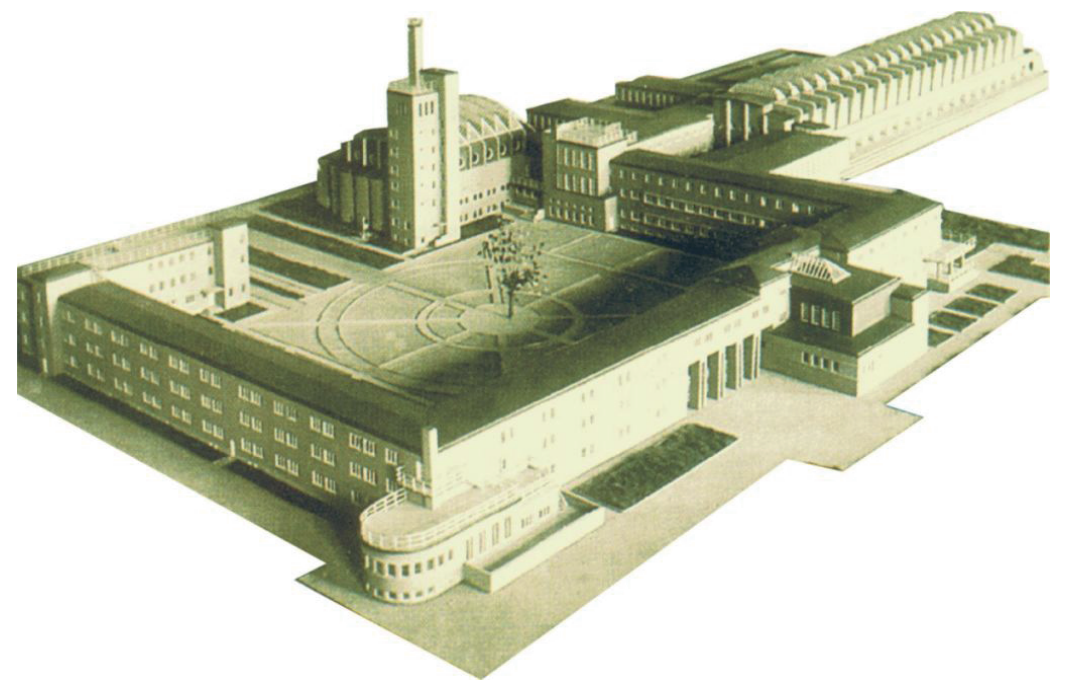

Ryc. 1. Centralny Instytut Wychowania Fizycznego Józefa Piłsudskiego w Warszawie (obecnie AWF Warszawa), proj. Edgar Norwerth, 1928

Źródło: Archiwum AWF Warszawa

znaleziono odpowiednieśrodkifinansowe z budżetuSkarbu Państwa, co pozwalało realizować nowoczesny zespół Centralnego Instytutu Wychowania Fizycznego na obszernej działce 73 ha na warszawskich Bielanach. Od samego początku realizację projektu koordynowano na poziomie rządowym, komitetem budowy kierował Minister Spraw Wewnętrznych, generał Felicjan Sławoj-Składkowski. Dzięki bezpośredniemu zaangażowaniu i wsparciu wojska, budowa kampusu CIWF, najpoważniejszej inwestycji ówczesnej Warszawy, przebiegała niezwykle sprawnie. Kamień węgielny położono już w czerwcu 1928, była to uroczystość, w której uczestniczyli przedstawiciele rządu i prezydent miasta. Tempo budowy kampusu było niezwykłe, biorąc pod uwagę możliwości technologiczne i sprzętowe, jakie były przed prawie stu laty do dyspozycji inwestora - już w następnym, 1929 r., w dniu 5 listopada uczelnia na Bielanach rozpoczęła zajęcia dla studentów (ryc. 1). 


\section{Projekt i realizacja kampusu uczelni na Bielanach}

Autorem projektu zespołu CIWF, utrzymanym w stylu modernizmu monumentalnego, był architekt Edgar Norwerth, profesor Wydziału Architektury Politechniki Warszawskiej. Należy podkreślić, że w architekturze tych obiektów, standardzie ich wykończenia obowiązywała, przy zachowaniu elegancji rozwiązań i racjonalności - przede wszystkim skromność i powściągliwość. W 1927 r. Józef Piłsudski przekazując środki na inwestycje sportowe z nadwyżek budżetowych zalecał daleko idące oszczędności: "Musicie pamiętać, że jesteśmy biedni. Polska jest na dorobku. (...) Za wyskoki będę karał, na pałace nie pozwalam” [Osmolski, Jeziorowski (red.) 1928]. W takim też surowym, ale jak się okazało ponadczasowym duchu stylistycznym modernizmu, wzniesiono kompleks obiektów sportowodydaktycznych na Bielanach projektu Edgara Norwertha ${ }^{1}$.

Edgar Norwerth, prace projektowe nad kampusem przyszłej uczelni rozpoczął od rozeznania programów funkcjonalnych i rozwiązań architektonicznych innych placówek tego typu w Europie. Było ich wówczas tylko kilka o programie na poziomie uniwersyteckim, nie licząc kilkunastu małych prywatnych szkół sportu, na których nie było sensu, zdaniem Norwertha, się wzorować. W rezultacie inspiracją dla kampusu CIWF na Bielanach nie stał się ani Instytut Wychowania w Sztokholmie (założony w połowie XIX w., o przestarzałych już wobec nowych wymagań rozwiązaniach i konstrukcji) ani budowana w tym samym czasie Szkoła Sportu Ferenzina pod Rzymem (zdaniem Norwertha pompatyczna i niefunkcjonalna). Natomiast Hochschule für Leibesübungen pod Berlinem została przez Norwertha uznana za najbardziej zbliżoną programowo do tego, co chciano osiągnąć w Warszawie. Projekt CIWF był także wzorowany na założeniach dla uczelni sportowej przygotowanych przez Eugeniusza Piaseckiego z Poznania.

Bez wątpienia jednak najbardziej istotną inspiracją dla Norwertha pod kątem kompozycji urbanistycznej i wyboru stylu architektury była wspomniana Wyższa Szkoła Wychowania Fizycznego w Gruenewaldzie pod Berlinem (Hochschule für Leibesübungen). Opierając się na doświadczeniach uczelni niemieckiej, polskim programie dydaktycznym oraz warunkach

\footnotetext{
${ }^{1}$ Edgar Aleksander Norwerth (1884-1950), był wybitnym polskim architektem, urbanistą i teoretykiem architektury, jednym z twórców modernizmu w architekturze polskiej. Studiował w Rosji, od $1924 \mathrm{r}$. mieszkał w Warszawie. W latach 1926-1930 prowadził wykłady na Wydziale Inżynierii Lądowej Politechniki Warszawskiej. Pracował na Politechnice Warszawskiej, prowadził pracownię projektowa, zajmował się grafiką (akwaforty i drzeworyty). Jego celne artykuły na temat teorii architektury były zamieszczane w czasopiśmie "Architektura i Budownictwo". Do jego najbardziej znanych prac (zrealizowanych) należą: dworzec kolejowy Będzin Miasto (1931), kompleks Centralnego Instytutu Wychowania Fizycznego (obecnie Akademia Wychowania Fizycznego im Józefa Piłsudskiego) na warszawskich Bielanach (1928-1930), pawilon GISZ wraz z kamienicą Wojskowej Spółdzielni Mieszkaniowej „Proporzec” („Dom Pułkowników”, „Dom Generalski”) przy Alei Szucha w Warszawie (1931), osiedle mieszkaniowe Funduszu Kwaterunku Wojskowego w rejonie Cytadeli Warszawskiej, Żoliborz Oficerski (1932-1937), Dom Wychowania Fizycznego i Przysposobienia Obronnego w Kielcach (1933), dom własny przy ulicy Klonowej w Warszawie (1939), odbudowa i przebudowa kościoła św. Stanisława Kostki na warszawskim Żoliborzu (1945-1963), odbudowa Miejskiego Gimnazjum i Liceum Handlowego przy ulicy Krypskiej w Warszawie (1948), odbudowa Towarzystwa Naukowego Warszawskiego przy ulicy Śniadeckich (1948). Edgar Norwerth jest pochowany na Cmentarzu Powązkowskim w Warszawie.
} 
terenowych i oczekiwaniach inwestora, Edgar Norwerth przygotował plany dla kampusu na 80 ha, położonego na malowniczej Skarpie Wisły, w sąsiedztwie Lasu Bielańskiego. Założenie zespołu dydaktyczno-sportowego było oparte na zasadzie dwóch krzyżujących się na centralnym placu CIWF osi: wschód-zachód (prostopadłej do Wisły, na przedłużeniu reprezentacyjnej Alei Zjednoczenia) oraz północ-południe (równoległej do Wisły i ulicy Marymonckiej). Osią wschód-zachód planowanego na Bielanach założeniach było przedłużenie Alei Zjednoczenia, która na kampusie rozpoczynałaby się bramą (przy ulicy Marymonckiej), a kończyłaby się w części wschodniej monumentalnym Stadionem Narodowym, ulokowanym już na granicy Skarpy Wiślanej.

Osią poprzeczną na linii północ-południe miał być budynek główny z krytą pływalnią (konstrukcja dachu wspierana przez ramy żelbetowe o rozpiętości $24 \mathrm{~m}$ ), salami wykładowymi (w tym aula na 250 miejsc), monumentalną halą ćwiczeń (o rzadko wówczas spotykanych rozmiarach: 130 m x 22 m, konstrukcji z 24 ram żelbetowych). Równolegle do budynków na osi północ-południe, w części północnej kompleksu, zaplanowano ciąg boisk sportowych (do piłki nożnej i rugby, ćwiczeń lekkoatletycznych, gimnastyki), lodowiskiem, salami do treningu, zapasów i judo, kortami tenisowymi i odkrytą pływalnią (ryc. 2, 3).

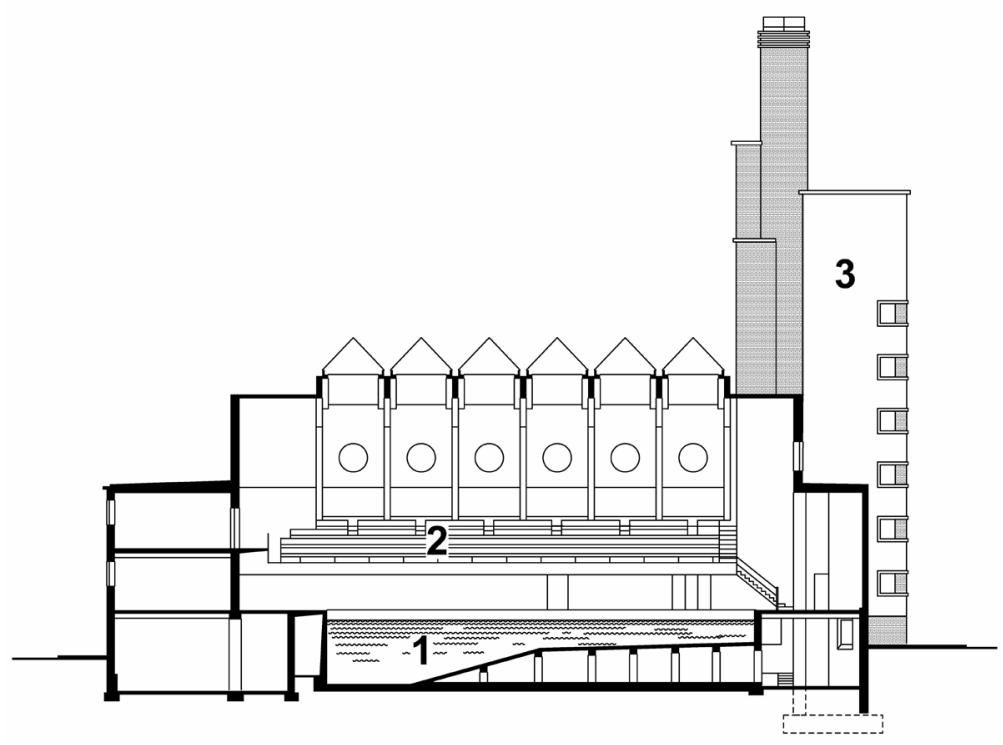

Ryc. 2. Projekt krytej pływalni dla CIWF w Warszawie, przekrój poprzeczny Objaśnienia: 1 - profil niecki basenu, 2 - trybuny dla widzów, 3 - wieża ciśnień (także funkcji mieszkalnej)

Źródło: na podstawie rysunków Edgara Norwertha z 1928 r. opracowanie: A. Pawlikowska-Piechotka, M. Piechotka (2016) 
Akademik męski (wraz z ambulatorium z osobnym wejściem) był zaplanowany w części południowej założenia, wzdłuż osi północ-południe, jako przedłużenie korpusu budynku głównego, natomiast dom akademicki żeński w części północnej, oderwany od korpusu budynku głównego. Domy mieszkalne dla wykładowców zaplanowano równolegle do budynków na osi południowej założenia.

Dominantą nad zespołem obiektów miała być wysoka na 36 metrów wieża ciśnień przy pływalni (posadowiona na osobnej płycie zbrojeniowej), ukrywająca w swoim korpusie „nieestetyczny, ale niezbędny" (według słów samego Norwertha) komin.

Projektantom założenia (Edgar Norwerth zaprosił do współpracy studentów z Wydziału Architektury Politechniki Warszawskiej) bardzo zależało na zachowaniu bujnej zieleni Lasu Bielańskiego. Stąd między innymi pomysł „Propylejów”, monumentalnych filarów, przez które widać drzewa, niestety nie udało się to w takim stopniu, w jakim o to zabiegali. Edgar Norwerth bardzo niepokoił się losem samotnej czarnej wierzby rosnącej w centrum założenia, ponieważ nie tylko cenił jej urodę, ale także uważał, że stanowi ważny akcent kompozycyjny dziedzińca głównego (obecnie drzewo jest otoczone prawna, indywidualną ochroną konserwatorska, jako cenny „Pomnik Przyrody”). Autorami projektów wnętrz uczelni (także projektów mebli wykonywanych na indywidualne zamówienie), dla kasyna, jadalni, sal internatów studenckich - byli zaproszeni do współpracy studenci z Politechniki, którzy starali się, pomimo skromnych środków na realizację, osiągnąć wygodę i elegancję. Styl w jakim zaprojektowano CIWF historycy określają jako „modernizm monumentalny”, możemy w nim jednak także znaleźć ślady ekspresjonizmu, szczególnie inspiracje projektami niemieckiego architekta Ericha Mendelsohna (np. charakterystyczne „podkreślenia” otworów okiennych).

Edgar Norwerth planował na elewacjach budynków tynki szlachetne, jednak ani wówczas ani obecnie nie jest to możliwe ze względu na brak środków. Nie wszystkie zamierzenia autorskie udało się zrealizować i Norwerth nieco gorzko pisał o tych narzucanych mu przez inwestora budowy ograniczeniach na łamach „Architektury i Budownictwa”: „Przy systemie skrajnej oszczędności, dążącej do możliwie jak najszerszego wykonania programu (...), nie mogło być mowy o jakimkolwiek podniesieniu się ponad poziom ścisłej użyteczności. Jedynym luksusem dekoracyjnym jaki w naszem rozporządzeniu pozostał - było piękne i bogate zadrzewienie terenu, to też nie żałowano wysiłków, do jak najszerszego wykorzystania go, z wyjątkową pieczołowitością starając się uwydatnić każdy nadający się moment dekoracyjny. Nie wszystkie się udały. Jedne przedwcześnie zginęły śmiercią naturalna, inne padły ofiarą żelaznej użyteczności. Pozostała, niewiadomo na jak długo, rozłożysta topola w środku podwórza, wspaniale ożywiająca skromny zarys murów" [Norwerth 1930, s. 426]. Pomimo koniecznych stałych oszczędności, o których autor projektu wspomina, pomimo niezrealizowania wszystkich elementów planowanego założenia (reprezentacyjnego stadionu, odkrytej pływalni, hali dla hokeja na lodzie, amfiteatru czy torów wioślarskich na Wiśle) bez wątpienia zespół CIWF należy śmiało uznać za wybitne dzieło kompozycji urbanistycznej, przykład niezrównanej harmonii i elegancji, funkcjonalnej i ponadczasowej kompozycji kampusu uczelni sportowej. Zespół obiektów uczelni, do dzisiaj dobrze służy kolejnym pokoleniom studentów i wykładowców - pod zmienioną nazwą Akademii Wychowania Fizycznego Józefa Piłsudskiego w Warszawie. 


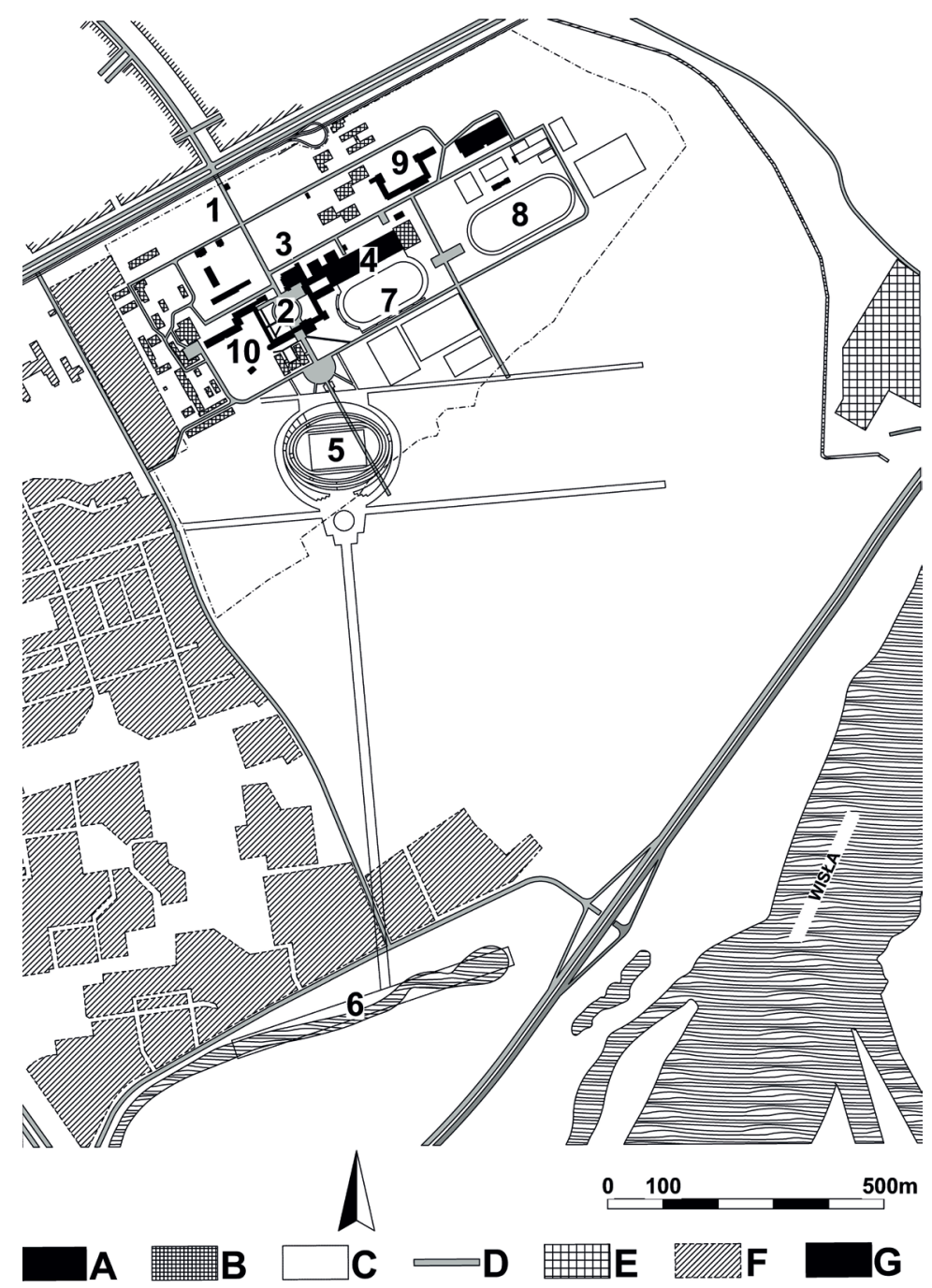

Ryc. 3. Plan zespołu CIWF (AWF) w Warszawie przy ulicy Marymonckiej 34 z naniesieniami zmianami inwestycyjnymi w latach 1928-2016

Objaśnienia: A - oryginalne realizacje wg Planów Edgara Norwertha z 1930 r., B - uzupełnienia zabudowy kampusu po 1945 r., C - niezrealizowane plany Edgara Norwertha, D - drogi, E - uzupełnienia infrastruktury sportowej po 1945 r., F - zabudowa mieszkaniowa poza granicami kampusu AWF, 1 - wejście główne, 2 - pływalnia kryta, 3 - budynki dydaktyczne i akademik żeński, 4 - domy pracowników, 5 - dziedziniec przed Gmachem Głównym, 6 - stadion lekkoatletyczny, 7 - stadion rugby, 8 - boisko, 9 - lokalizacja Stadionu Narodowego (obiekt niezrealizowany), 10 - lokalizacja toru wioślarskiego (obiekt niezrealizowany), 11 - ulica Marymoncka, 12 - Aleja Zjednoczenia, 13 - Wisła, 14 - Kościół i klasztor oo. Kamedułów, 15 - rezerwat Las Bielański

Źródło: na postawie różnych źródeł, opracowanie: A. Pawlikowska-Piechotka, M. Piechotka (2016) 


\section{Lata 1929-1945}

Uroczysta inauguracja pierwszego roku akademickiego 1929/1930 miała miejsce w dniu 29 listopada 1929 r., chociaż już trzy tygodnie wcześniej rozpoczęto zajęcia ze studentami. Dla upamiętnienia tego niezwykle doniosłego wydarzenia, w tym dniu corocznie obchodzone jest „Święto Uczelni”.

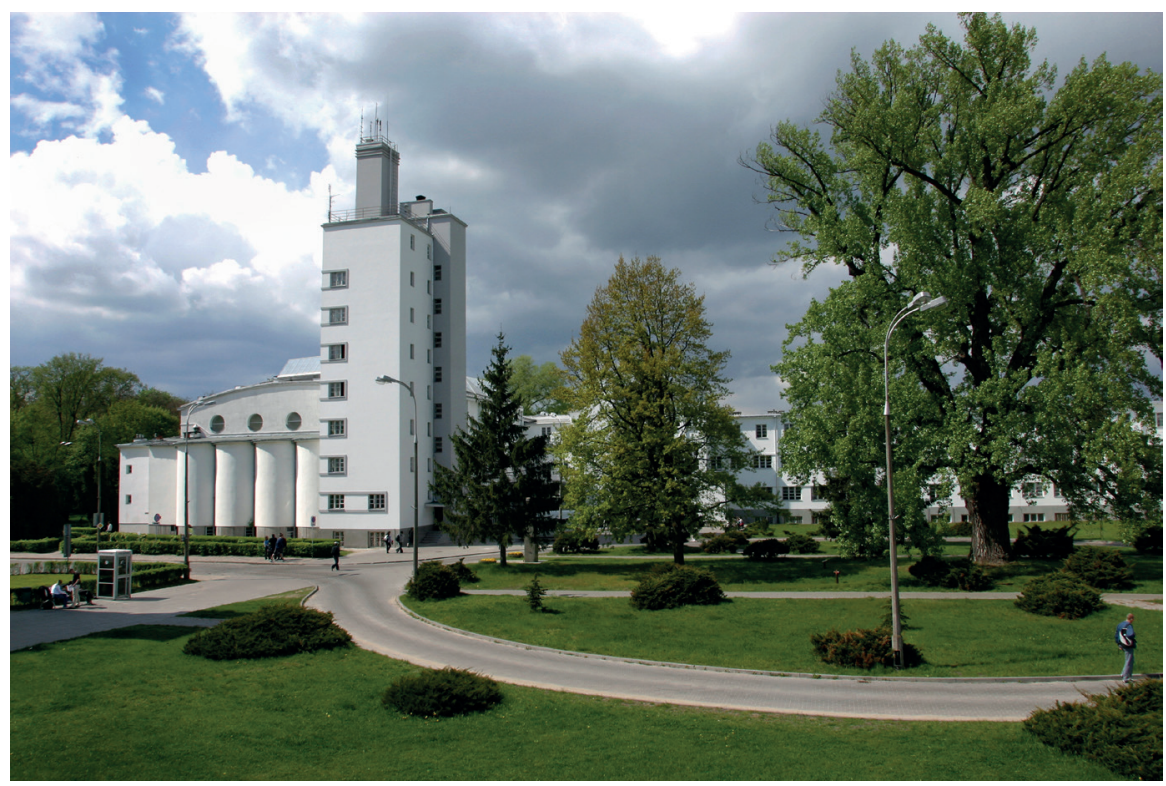

Ryc. 4. Widok krytej pływalni AWF Warszawa, proj. E. Norwerth 1928 r., stan obecny

Fot. M. Godlewska, 2004, archiwum AWF Warszawa

W 1930 r. warszawski CIWF połączono z Centralną Wojskową Szkołą Gimnastyki i Sportów (CWSGiS) w Poznaniu. Były to zawodowe uczelnie wojskowe z programem 2-letnich studiów oraz 1-rocznym kursem oficerskim, co warto podkreślić, otwartych także dla kobiet. Od 1936 r. studia na CIWF trwały 3 lata, absolwenci otrzymywali uprawnienia ujednolicone z absolwentami studiów uniwersyteckich. W 1938 r. CIWF imienia Pierwszego Marszałka Polski Józefa Piłsudskiego został przekształcony w Wojskową Szkołę Akademicką pod nazwą Akademia Wychowania Fizycznego Józefa Piłsudskiego w Warszawie.

Aż do wybuchu II wojny światowej w CIWF, poza programem dydaktycznym, prowadzono badania naukowe w obszarze kultury fizycznej i sportu, uczelnia bielańska była miejscem treningów, zawodów oraz ważnych imprez sportowych. Wielką atrakcją w ofercie ówczesnych obiektów sportowych w Warszawie była kryta pływalnia CIWF - jedna z kilku zaledwie w przedwojennej stolicy - obok YMCA, Domu Studenta przy Placu Narutowicza oraz Yacht Clubu Oficerskiego nad Wisłą (ryc. 4, 5). 


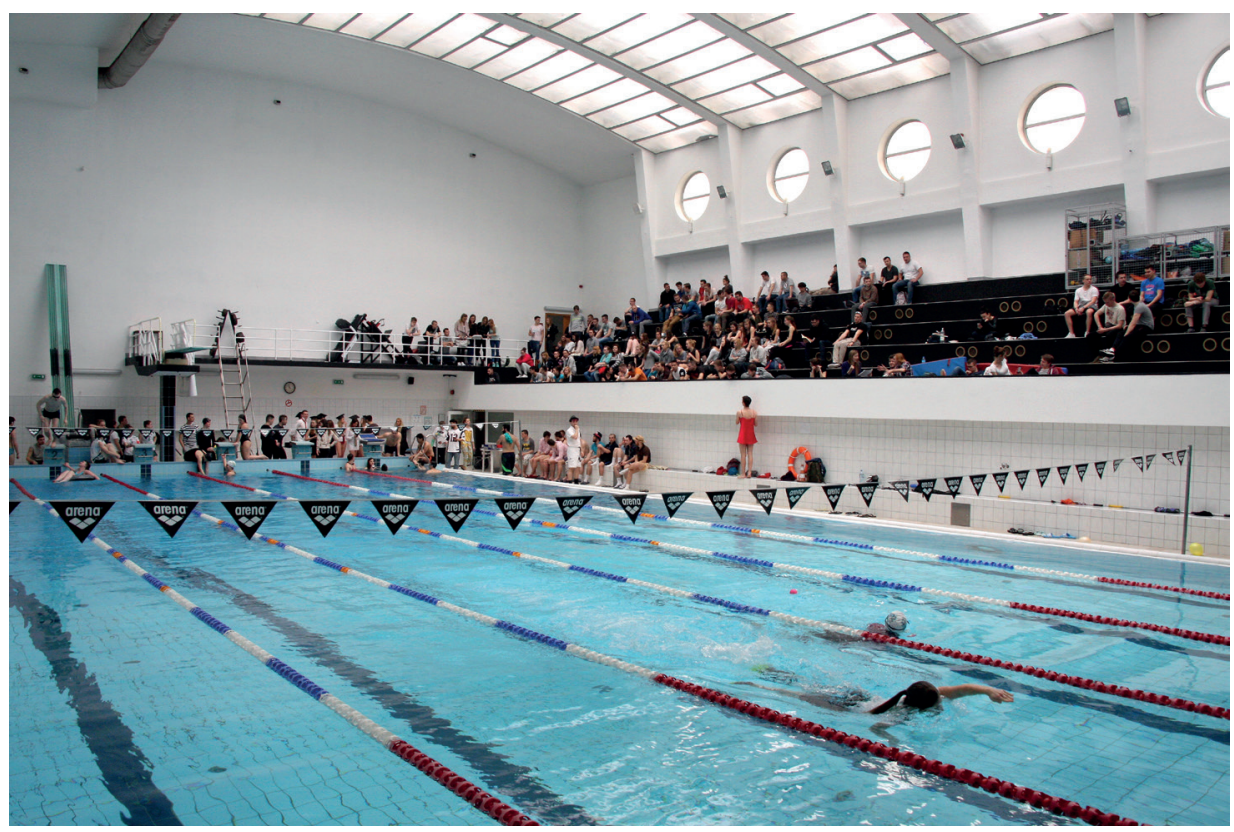

Ryc. 5. Pływalnia kryta AWF Warszawa, proj. E. Norwerth, 1928, stan obecny (wnętrze w czasie zawodów)

Fot. M. Godlewska, 2008, archiwum AWF Warszawa

W okresie II wojny światowej uczelnia została zamknięta, w obiektach kampusu stacjonowały wojska niemieckie, oddziały Luftwaffe. Wielu pracowników i studentów uczelni poniosło śmierć w czasie działań wojennych, w czasie okupacji, Powstania w Getcie i Powstania Warszawskiego. Wśród nich olimpijczycy i medaliści, m.in. Janusz Kusociński, Bronisław Czech, Eugeniusz Lokajski.

W wyniku działań wojennych 1939-1945 zniszczona została cenna baza materialna uczelni: obiekty dydaktyczne, infrastruktura sportowa, zbiory biblioteczne i laboratoria naukowe.

\section{Lata 1945-1990}

Po zakończeniu II wojny światowej uczelnia rozpoczęła działalność już 2 grudnia 1946 r., przyjmując grupę ponad stu dziewcząt i chłopców, nie bacząc na zły stan obiektów sportowodydaktycznych, dotkliwe braki bazy materialnej i niedostatki kadry nauczycieli akademickich. W konsekwencji aż do lat 50. trwały remonty i odbudowa zniszczonych działaniami wojennymi obiektów dydaktyczno-sportowych. Kampus uczelni uzupełniano też obiektami nowymi - np. zbudowano w charakterystycznym dla socrealizmu, wówczas powszechnie obowiązującym stylu, wolnostojący pawilon stołówki z monumentalnymi „paradnymi” schodami. 


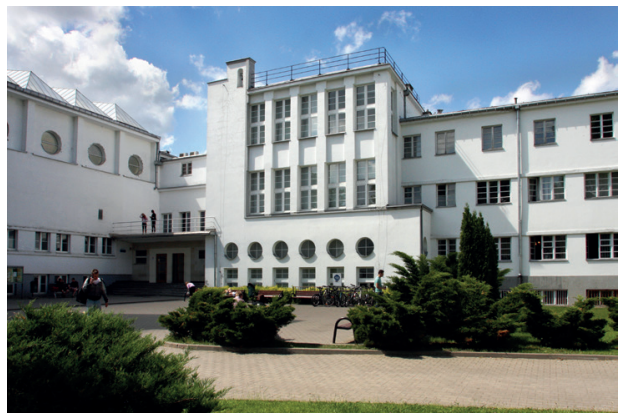

Ryc. 6. Widok Gmachu Głównego AWF Warszawa, stan obecny

Fot. M. Godlewska, 2004, archiwum AWF Warszawa

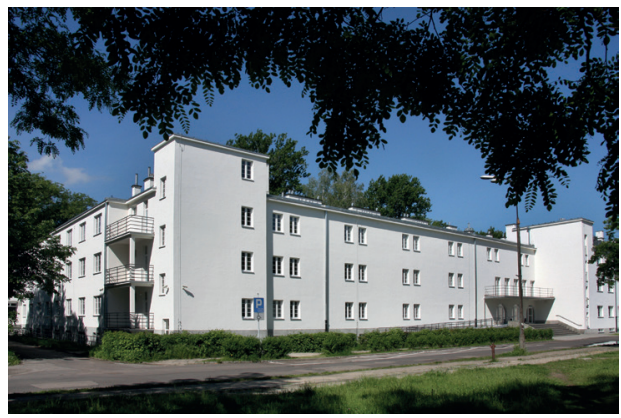

Ryc. 7. Widok budynku dydaktycznego AWF Warszawa, stan obecny

Fot. M. Godlewska, 2014, archiwum AWF Warszawa

Na mocy Dekretu Rady Ministrów w 1949 r. uczelnia została przekształcona w cywilny ośrodek akademicki, otrzymując nową nazwę i patrona - Akademia Wychowania Fizycznego im. generała Karola Świerczewskiego. W jej ramach funkcjonował Wydział Wychowania Fizycznego, a na czele uczelni stał rektor. Nadzór organizacyjny i merytoryczny nad uczelnią sprawował Główny Komitet Kultury Fizycznej. W 1949 r. powołano uczelniany klub sportowy AZS - AWF Warszawa, którego wybitni zawodnicy przeszli do historii polskiego sportu: Waldemar Baszanowski, Jerzy Kulej, Jacek Wszoła, Paweł Nastula, Mateusz Kusznierewicz, Otylia Jędrzejczyk, Paweł Korzeniowski.

$\mathrm{W}$ połowie lat 50. wprowadzono jednolite, 4-letnie studia magisterskie, uruchomiono w ramach wydziału specjalizacje trenerskie oraz rehabilitacji ruchowej. Od 1959 r. AWF Warszawa otrzymała jako pierwsza w kraju prawo nadawania stopnia doktora w zakresie nauk o kulturze fizycznej, a od 1966 r. - uprawnienia do przeprowadzania przewodów habilitacyjnych w tej samej dziedzinie. Od 1970 r. istnieje filia uczelni w Białej Podlaskiej. W 1984 r. powołano w ramach uczelni Wydział Rehabilitacji (ryc. 6, 7, 8).

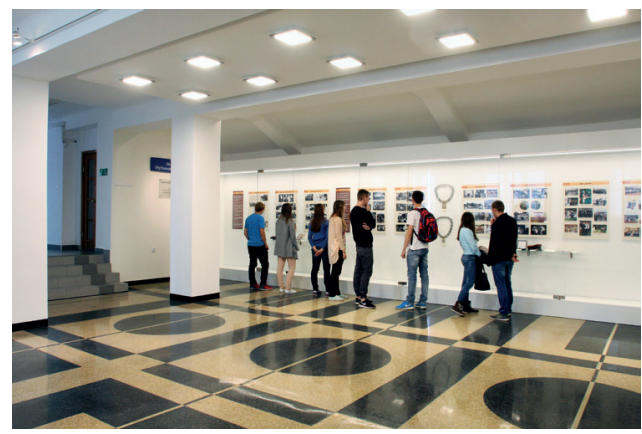

Ryc. 8. Pływalnia kryta AWF Warszawa, proj. E. Norwerth, 1928, stan obecny (wnętrze w czasie zawodów)

Fot. M. Godlewska, 2014, archiwum AWF Warszawa 
W latach 60. i 70. kontynuowano modernizację i rozbudowę uczelni: wzniesiono kolejne obiekty dydaktyczne i sportowe, domy studenckie, cztery pawilony do treningów (boks, judo i zapasy, podnoszenie ciężarów i szermierka), halę lekkoatletyczna, halę gier, Centrum Medycyny Sportowej (ryc. 9, 10, 11).

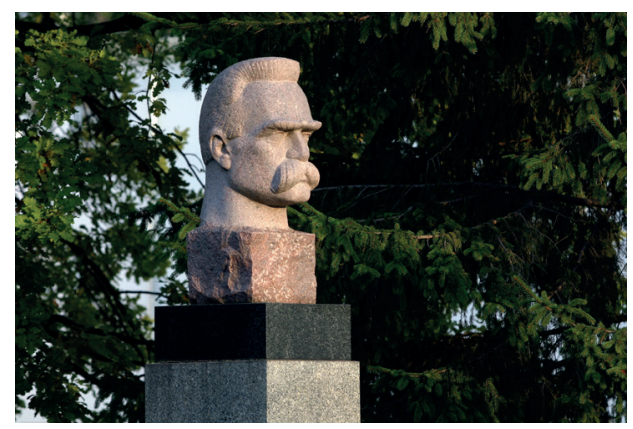

Ryc. 9. AWF w Warszawie. Pomnik Józefa Piłsudskiego, założyciela CIWF w Warszawie i obecnie patrona uczelni

Fot. M. Godlewska, 2008, archiwum AWF Warszawa

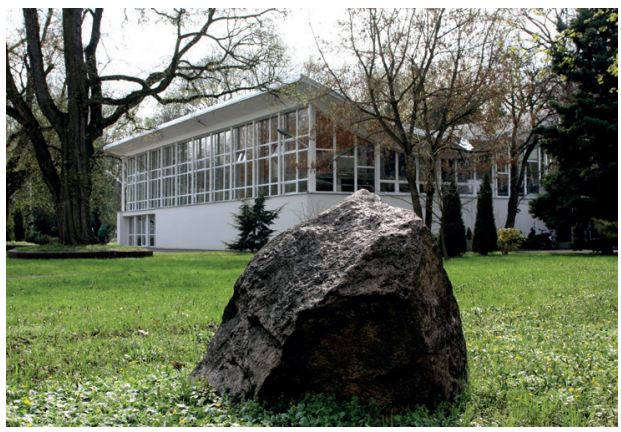

Ryc. 10. Pawilon walk (widok elewacji od strony północno-wschodniej), AWF Warszawa, proj. W. Zabłocki

Fot. M. Godlewska, 2014, archiwum AWF Warszawa

Autorem większości wymienionych obiektów jest prof. Wojciech Zabłocki, wybitny olimpijczyk, mistrz szermierki i znakomity architekt, zasłużony w dziedzinie poszukiwań nowatorskich i eleganckich rozwiązań obiektów sportowych. Wśród najbardziej znanych projektów tego autora należy wymienić projekty dla warszawskiej AWF: nowej sali gier, Ośrodek Przygotowań Olimpijskich (pawilony sportów walki); a ponadto w Warszawie Halę Sportową „,Mera”, kompleks sportowy w Koninie, Centrum Sportowe w Zgorzelcu, ośrodek sportu w Puławach, tor kolarski w Pruszkowie. Wojciech Zabłocki jest także autorem wielu innych obiektów sportowych poza granicami Polski (m.in. na Bliskim Wschodzie). Wojciech Za-

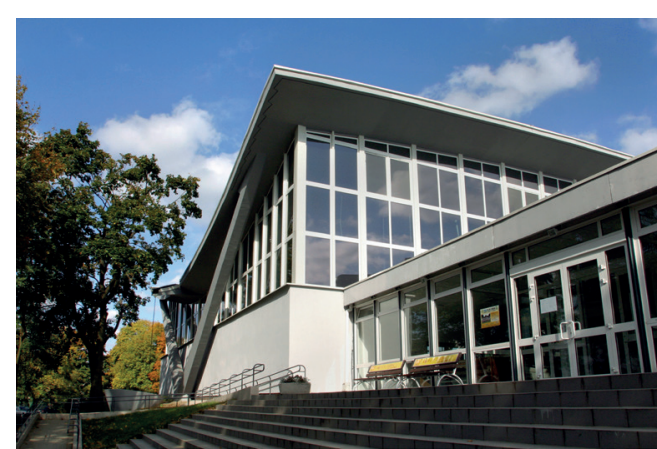

Ryc. 11. Hala gier (widok elewacji zachodniej) AWF Warszawa, proj. W. Zabłocki

Fot. M. Godlewska, 2014, archiwum AWF Warszawa błocki (przy współpracy ze Stanisławem Kusiem) był autorem Specjalistycznego Olimpijskiego Ośrodka Treningowego na AWF w Warszawie (projekt 1962, realizacja 1964), składających się z dwóch pawilonów, w każdym dwie sale o wymiarach $15 \mathrm{~m}$ x $30 \mathrm{~m}$. Sale do treningu szermierki, judo, boksu i podnoszenia ciężarów mają niewielkie trybuny dla widzów. Zostały znakomicie wkomponowane $\mathrm{w}$ istniejący starodrzew AWF-owskich kasztanowców. Mają bardzo ciekawa, lekką i elegancką konstrukcję dachów z trójkątnych żelbetowych prefabrykatów sprężonych w formie 
wklęsłej siatki cylindrycznej, spoczywającej na stalowych słupach na obwodzie. Autor tak opisuje koncepcję projektu: „Powyżej 2.70 m sale treningowe są ze wszystkich stron przeszklone, co daje iluzję zawieszenia lekkich wklęsłych dachów miedzy drzewami i stwarza atrakcyjny klimat wnętrza" [Zabłocki 2007, s. 23-27]. Sala gier (do rozgrywek koszykówki i piłki ręcznej) w Akademii Wychowania Fizycznego w Warszawie została zaprojektowana przez Wojciecha Zabłockiego przy współpracy ze Stanisławem Kusiem i Romanem Wilczyńskim (projekt 1970, realizacja 1974). Sala została dobudowana do istniejącej hali lekkoatletycznej projektu Edgara Norwertha. Konstrukcja przykrycia areny sportowej o wymiarach $32,5 \mathrm{~m}$ x $45 \mathrm{~m}$ jest rozwiązana jako wisząca na linach, liny co 2,5 m zakotwione są w żelbetowych belkach, dwa charakterystyczne pochyłe słupy - zastrzały w kształcie litery „,V” maja zadanie stabilizacji konstrukcji i stanowią interesujący rzeźbiarski wyróżnik dla bryły. Arena może pomieścić 800 widzów (ryc. 12, 13).

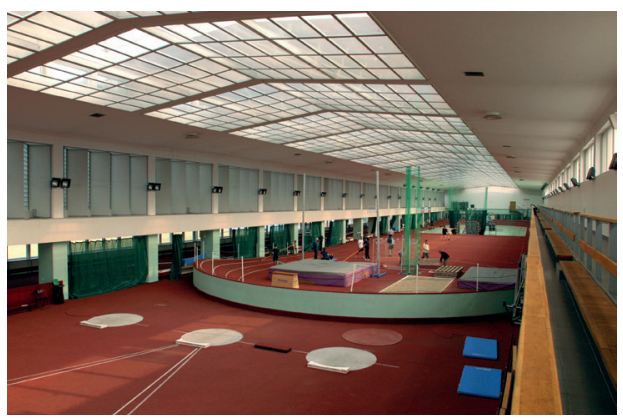

Ryc. 12. Hala gier (wnętrze), AWF Warszawa proj. W. Zabłocki

Fot. M. Godlewska, 2014, archiwum AWF Warszawa

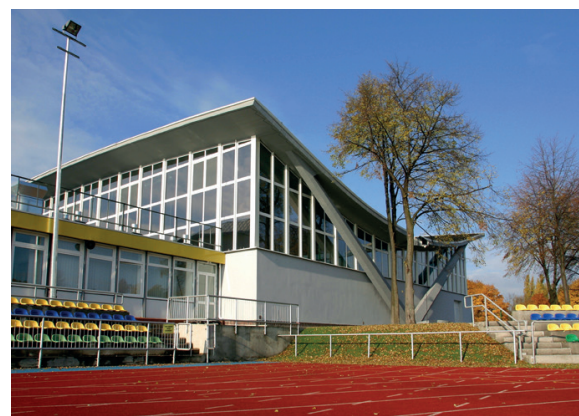

Ryc. 13. Hala gier (widok elewacji od strony wschodniej), AWF Warszawa proj. W. Zabłocki

Fot. M. Godlewska, 2014, archiwum AWF Warszawa

\section{Okres po 1990 roku}

W 1990 r. Sejm RP przywrócił uczelni historyczną nazwę z 1938 r. - Akademia Wychowania Fizycznego Józefa Piłsudskiego w Warszawie.

Obecnie w strukturze uczelni (razem z filią w Białej Podlaskiej) jest pięć wydziałów: Wydział Rehabilitacji, Wydział Turystyki i Rekreacji, Wydział Wychowania Fizycznego, Wydział Wychowania Fizycznego i Sportu oraz Wydział Turystyki i Zdrowia, na których jest kształconych ponad 4557 studentów. Zajęcia dydaktyczne są prowadzone na następujących kierunkach: wychowanie fizyczne, sport, turystyka i rekreacja, fizjoterapia, pielegniarstwo, terapia zajęciowa, kosmetologia, trener personalny oraz wychowanie fizyczne w służbach mundurowych. Dzienne studia I stopnia (licencjackie), II stopnia (magisterskie) i III stopnia (doktoranckie), w zależności od zainteresowania i potrzeb na rynku edukacyjnym, są uzupełniane kursami zaocznymi. Ponadto uczelnia ma w ofercie studia podyplomowe, kursy specjalistyczne, szkolenia i warsztaty. Na uczelni zatrudnionych jest obecnie 369 nauczycieli akademickich [http/www.awf.edu.pl, dostęp: 2019]. 
Rok 2019 jest dla Akademii Wychowania Fizycznego Józefa Piłsudskiego rokiem szczególnym, z uwagi na 90. rocznicę założenia uczelni. W latach 1929-2019 mury uczelni opuściło ponad 50000 absolwentów, wypromowano licznych doktorów i doktorów habilitowanych, zbudowano poważny potencjał naukowo-badawczy. Absolwenci mają wysokie kwalifikacje, odpowiadające potrzebom społeczeństwa XXI w.: są zatrudniani jako nauczyciele, trenerzy, instruktorzy, fizjoterapeuci, pielęgniarze, kosmetolodzy i specjaliści terapii zajęciowej - są doceniani w Polsce i w Europie.

Uczelnia stale współpracuje z kilkudziesięcioma ośrodkami w Europie i krajach pozaeuropejskich.

Z okazji Jubileuszu uczelni organizowane są w roku 2019 konferencje naukowe, sympozja, publikacje, wystawy, imprezy sportowe i kulturalne - podkreślające tradycję i podsumowujące dorobek tego ośrodka akademickiego.

\section{Literatura}

Norwerth E., 1930, Centralny Instytut Wychowania Fizycznego na Bielanach w Warszawie, Architektura i Budownictwo, 11, s. 420-429.

Osmolski W., Jeziorowski H. (red.), 1928, Budowa terenów i urządzeń sportowych, Główna Księgarnia Wojskowa, Warszawa.

Pawlikowska-Piechotka A., Piechotka M., 2017, Dzieje obiektów sportowych w Europie, Wydawnictwo Naukowe Akademii Wychowania Fizycznego Józefa Piłsudskiego w Warszawie, Warszawa.

Zabłocki W., 2007, Architektura, Wydawnictwo BOSZ, Lesko.

\section{Strony internetowe}

www.awf.edu.pl [dostęp: wrzesień 2019]

\section{The 90th Anniversary of the Józef Piłsudski University of Physical Education in Warsaw}

\section{ABSTRACT}

2019 is a special year, due to the 90th anniversary of the founding of the Józef Piłsudski University of Physical Education. During 1929-2019, more than 50,000 graduates left the walls of the university, numerous doctors and habilitated doctors were promoted, and serious research and development potential was created. Currently, about 4,557 students attend five faculties and nine fields of education. All graduates are highly qualified and meet the needs of the 21st-century society: they are employed as teachers, trainers, instructors, physiotherapists, nurses, cosmetologists and occupational therapy specialists - they are highly appreciated in Poland and other countries in Europe.

Various scientific conferences, symposia, publications, exhibitions, sporting and cultural events are organized on the occasion of the Anniversary. They are emphasizing the tradition and summarizing the achievements of the Józef Piłsudski University of Physical Education in Warsaw.

Key words: AWF Warsaw, history and tradition of the university, 90th anniversary 